\title{
HELLP Sendromu Tanısı Alan Hastaların Maternal ve Fetal Sonuçlarının Analizi
}

\author{
Analysis of Maternal and Fetal Outcomes of Patients Diagnosed with HELLP Syndrome
}

\section{Ümmügülsüm ESENKAYA ${ }^{1}$, Metin İNGEÇ ${ }^{2}$ Emsal Pınar Topdağı YILMAZ ${ }^{3}$, Şengül Talar ARSLAN ${ }^{3}$}

1. Beyşehir Devlet Hastanesi, Kadın Hastalıkları ve Doğum Bölümü, Konya

2. Atatürk Üniversitesi Tıp Fakültesi Kadın Hastalıkları ve Doğum Bölümü, Erzurum

3. Nenehatun Kadın Doğum Hastanesi, Kadın Hastalıkları ve Doğum Bölümü Erzurum

\section{$\ddot{O} Z E T$}

Amaç: HELLP sendromu, maternal ve fetal iyilik durumunun hizl şekilde bozulmasina neden olan, multisistemik bir hastalıktır. Çalışmamızda HELLP sendromu tanisı konulan hastalarda görülen maternal ve perinatal sonuçlarl etkileyen klinik ve laboratuar parametreleri ile maternal ve perinatal morbidite ve mortalite arasindaki ilişkiyi incelemeyi amaçladık.

Gereç ve Yöntem: Bu çalışmada, kliniğimizde Ocak 2005 ile Aralı 2010 tarihleri arasinda HELLP sendromu tanlsi konulan 155 hastanın, hastane bilgisayar sistemindeki kayıtları geriye dönük olarak değerlendirildi. Hastaların demografik özellikleri, maternal ve perinatal sonuçlar, laboratuar parametreleri analiz edildi.

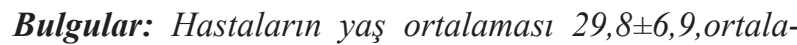

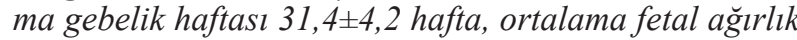
$1672,72 \pm 726 \mathrm{gr}$ olarak tespit edildi. Hastaların \%61'i multigravida, \%39'u primigravida idi. En çok karşılaşllan maternal komplikasyonlar; 58 hastada (\%37.4) transfüzyon ihtiyacı idi. Maternal komplikasyon gelişmeyen hastalar ile en az bir adet komplikasyon gelişen hastalar arasinda AST, LDH, kreatinin, trombosit saylsi, total bulirubin değerleri arasında anlamlı farklılık tespit ettik. Prematürite oranı ise \%83.4 olarak tespit edildi. 12 hastada $(\% 7,7)$ maternal mortalite, 9 hastada (\%12) perinatal mortalite tespit edildi.

Sonuç: HELLP sendromu maternal-fetal mortalite ve morbiditeyi artırmaktadır. Erken teşhis ve doğru tanı HELLP sendromunun prognozunu belirlemede en önemli noktayı oluşturmaktadır.

Anahtar Kelimeler: HELLP; maternal; yeni doğan; morbidite; mortalite

\section{İletişim Bilgileri}

Sorumlu Yazar: Emsal Pınar Topdağı YILMAZ

Yazışma Adresi: Nenehatun Kadın Doğum Hastanesi, Kadın

Hastalıkları ve Doğum Bölümü Erzurum

E-posta: emsalpinar1@hotmail.com

Tel: +90 (505) 9436866

Makalenin Geliş Tarihi: 15.02.2016

Makalenin Kabul Tarihi: 13-11-2016

DOI: http://dx.doi.org/10.16948/zktipb.237221

\section{ABSTRACT}

Objective: HELLP syndrome is a multisystem disorder which causes rapid deterioration of maternal and fetal well-being. In this study, we aimed to investigate clinical and labaratory parameters that influencing maternal and perinatal outcomes in addition to relatonship between maternal and perinatal morbidity and mortalitiy in patients which had been diagnosed as HELLP syndrome.

Material and Method: In this study, the hospital's computer system records of 155 patients diagnosed with HELLP syndrome in our clinic between January 2005 and December 2010 were reviewed retrospectively.The demographic characteristics of the patients, maternal and perinatal outcomes and laboratory parameters were analyzed.

Results: The average age of the patients was $29.8 \pm 6.9$ year, the mean gestational age was $31.4 \pm 4.2$ week, the mean fetal birth weight was $1672.72 \pm 726$ gr. Sixty-one percent of patients were multigravida while 39\%of patients were primipar. The most common maternal complications were the transfusion requirement in 58 patients (37.4\%). We found significant differences between patients who developed at least one complications and no maternal complication with regard to AST, LDH, creatinine, thrombocyte, and total bilirubine levels. Prematurity rate was detected as $83.4 \%$. Maternal mortality was occurred in 12 patients (7.7\%).Perinatal mortality was occurred in 9 patients (12\%).

Conclusion: HELLP syndrome increases maternal-fetal morbidity and mortality. Early diagnosis and appropriate treatment are important in determining the prognosis of HELLP syndrome.

Keywords: HELLP; newborn; maternal; morbidity; mortality 


\section{GíRIŞ}

HELLP sendromu hemoliz, karaciğer enzimlerinin artıșı ve trombosit sayısının düşmesiyle karakterizedir [1]. Tipik olarak 27. gebelik haftası ile doğum arasındaki süreçte görülmekle birlikte, vakaların \%15-30'u erken postpartum dönemde görülmektedir [2]. Maternal ve fetal iyilik durumunun ani ve çoğu zaman da hızlı şekilde bozulması ile karakterizedir. Maternal mortalite $\% 1-3$, perinatal mortalite ise $\% 35$ oranında bildirilmiştir [3-5]. Çalışmamızda HELLP sendromu tanısı ile takip edilmiş olan hastalarımızın demografik özellikler ve laboratuvar verileri retrospektif olarak incelenerek maternal ve perinatal sonuçları etkileyen risk faktörlerinin değerlendirilmesi planland.

\section{GEREÇ VE YÖNTEM}

Bu retrospektif çalışma; Atatürk Üniversitesi, Tıp Fakültesi Etik Kurul onayı ile Helsinki kriterlerine uygun olarak gerçekleștirildi. Kliniğimizde Ocak 2005 ile Aralık 2010 tarihleri arasinda HELLP sendromu tanisi konulan 155 hastanın, hastane bilgisayar sistemindeki kayıtları geriye dönük olarak değerlendirildi. HELLP sendromu tanıs1 Sibai [5] tanı kriterlerine göre koyuldu.

-Hemoliz (periferik kan yaymasinda fragmente eritrositlerin varlığ 1 , serum $\mathrm{LDH} \geq 600$ $\mathrm{U} / \mathrm{L}$ ve serum total bilirubin $\geq 1.2 \mathrm{mg} / \mathrm{dl}$ ),

-Yüksek karaciğer enzimleri (Alanin transaminotransferaz $\geq 70 \mathrm{U} / \mathrm{L}$ ve/veya aspartat aminotransferaz $\geq 70 \mathrm{U} / \mathrm{L}$ )

-Düşük trombosit sayıs1 $\left(<100.000 / \mathrm{mm}^{3}\right)$ Hastaların demografik özellikleri (yaş, gravida, parite, gebelik haftası), doğum şekli, maternal ve perinatal sonuçlar kaydedildi. Gebelik haftas1 son adet tarihine göre veya ilk timester ultrason raporuna göre belirlendi. Ayrıca laboratuar parametreleri (tam kan sayımı, karaciğer fonksiyon testleri, böbrek fonksiyon testleri, spot idrarda proteinüri varlığı) kaydedildi. Maternal komplikasyonlar olarak; akut böbrek yetmezliği (ABY), dissemine intravasküler koagulasyon (DIC), kan ve kan ürünleri transfüzyonu ihtiyac1, plasenta dekolmanı, intrakranial kanama, subkapsüler hematom, eklampsi, beyin ödemi, sepsis, akut respiratuar distres sendromu, mekanik ventilasyon ihtiyac1, maternal mortalite durumu kaydedildi.Akut böbrek yetmezliği tanısı oligüri veya anüriye eșlik eden yükselmiş serum kreatinin değerinin $(\geq 2 \mathrm{mg} / \mathrm{dL})$ varlığ 1 ile tanımlandi. DIC tanısı ise aşağıdaki kriterlerden 3 veya daha fazlasının saptanması sonucu konuldu [6]:

- Düşük trombosit sayısı $\left(100.000 / \mathrm{mm}^{3}\right)$

- Düşük fibrinojen değeri $(<300 \mathrm{mg} / \mathrm{dL})$

- Pozitif D-Dimer ( $\geq 40 \mathrm{mg} / \mathrm{dL})$
- Uzamış protrombin zamanı ( $\geq 14 \mathrm{sn}$ )

- Uzamış parsiyel tromboplastin zamanı $(\geq 40$ sn)

Yeni doğanın doğum haftası ve doğum kilosu kaydedildi. Respiratuvar distres sendromu (RDS), fototerapi ihtiyac1, nekrotizan enterokolit (NEC), mekanik ventilatör ihtiyacı gibi neonatal komplikasyonlar varlığı kaydedildi. Maternal ve perinatal mortalite araştırıldı. Perinatal mortalite, intrauterin fetüs ölümü ile ilk yedi gün içinde yenidoğan ölümü olarak tanımland1. Elde edilen nicel veriler ortalama \pm standart sapma ile nitel veriler ise siklık (yüzde) olarak verildi. Nitel veriler "Ki-kare testi ve Fisher exact testi" ile nicel veriler ise "bağımsız örneklem t testi" ile değerlendirildi. Maternal ve perinatal komplikasyonlar için risk faktörlerini saptamada tek değişkenli lojistik regresyon analizi kullanıldı. Tüm istatistiksel analizler SPSS 15.0 for Windows paket programı kullanılarak gerçekleştirildi. İstatistiksel anlamlılık düzeyi $\mathrm{p}<0.05$ olarak kabul edildi.

\section{BULGULAR}

Çalıșmamıza dahil edilen 155 hastanın demografik özellikleri Ttablo 1'de gösterildi. Hastaların ortalama yaşı $29,8 \pm 6,9$ yıldı. Hastaların 60’1 (\%39) primigravida, 95'i(\%61) multigravida idi. Tanı anında gebelik haftasının ortala-

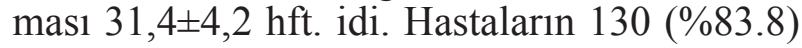
tanesinin gebelik haftasının 37 haftanın altında olduğu ve $25(\% 16,1)$ tanesinin gebeliğinin ise 37 hafta ve üzerinde olduğu görüldü. Hastaların kan basincı oturur pozisyonda 15 dakika istirahati müteakiben ERKA marka tansiyon aleti kullanılarak 5 dakika aralıklarla iki kez ölçüldü. 23 hastanın (\%15) arterial kan basincı değeri 140/90 mmHg değerinin altında iken, 132 (\%85) arterial kan basıncı değeri 140/90 mmHg ve üzerinde olduğu görüldü. Hastaların 121 $(\% 77,8)$ tanesi antepartum dönemde, 34 tanesi $(\% 22,2)$ ise postpartum dönemde tanı almıştır.

Tablo 1: HELLP sendromu tanısı alan hastaların demografik özellikleri.

\begin{tabular}{|l|l|}
\hline \multicolumn{1}{|c|}{ Demografik Özellikler } & \multicolumn{1}{c|}{ Değerler } \\
\hline Yaş (yı) & $29,8 \pm 6,9$ \\
\hline Gravida & $3,5 \pm 2,7$ \\
\hline Parite & $2,1 \pm 2,4$ \\
\hline Primigravida & $60(39)$ \\
\hline Multigravida & $95(61)$ \\
\hline Gebelik haftası & $31,4 \pm 4,2$ \\
\hline Ortalama sistolik kan basıncı (mmHg) & $158,90 \pm 28$ \\
\hline Ortalama diastolik kan basıncı (mmHg) & $98,25 \pm 16$ \\
\hline
\end{tabular}

Sonuçlar ortıss veya $\mathrm{n}(\%)$ olarak verilmiştir. 
HELLP sendromu tanisi alan hastalar spot idrardaki proteinüri değerleri açısından incelendiğinde; hastaların \%3,2'sinde proteinüri yok iken, $\% 77,4$ 'ünde ise proteinüri +3 ve üzeri tespit edilmiştir (Tablo 2).

Tablo 2: HELLP sendromu tanısı alan hastaların spot idrardaki proteinüri değerleri.

\begin{tabular}{|l|l|}
\hline \multicolumn{1}{|c|}{ Proteinüri Dağılımı } & \multicolumn{1}{|c|}{ Sonuçlar } \\
\hline Protein negatif veya eser $n(\%)$ & $5(3,2)$ \\
\hline+1 proteinüri $n(\%)$ & $7(12,7)$ \\
\hline+2 proteinüri n(\%) & $23(14,8)$ \\
\hline +3 ve üzeri proteinüri $n(\%)$ & $120(77,4)$ \\
\hline
\end{tabular}

En s1k karşılașılan maternal komplikasyonun kan ürünleri transfüzyon gereksinimi $(\mathrm{n}=58, \% 37,4)$ olduğu görüldü. Yapılan tüm tıbbi müdahalelere rağmen $12(\% 7,7)$ hastada maternal ölüm ortaya çıktı (Tablo 3).

Tablo 3: HELLP sendromu tanısı alan hastalarda gelişen maternalkomplikasyonlar.

\begin{tabular}{|l|l|}
\hline \multicolumn{1}{|c|}{ Maternal Komplikasyonlar } & \multicolumn{1}{|c|}{$\mathbf{n}(\%)$} \\
\hline Akut böbrek yetmezliği & $26(16,8)$ \\
\hline Pulmoner ödem & $11(7,1)$ \\
\hline DIC & $16(10,3)$ \\
\hline Dekolman plasenta & $14(9,1)$ \\
\hline İntrakranial kanama & $10(6,5)$ \\
\hline Kan ve kan ürünleri transfüzyon intiyacl & $58(37,4)$ \\
\hline Akut respiratuar distres sendromu & $1(0,6)$ \\
\hline Mekanik ventilasyon & $21(13,5)$ \\
\hline Sepsis & $3(1,9)$ \\
\hline Maternal ölüm & $12(7,7)$ \\
\hline Eklampsi & $29(13,7)$ \\
\hline
\end{tabular}

HELLP sendromu tanisı alan hastaların 151 tanesinin sezeryan ile, 4 tanesinin ise vajinal yolla doğum yaptırıldı. Hastaların ortalama gebelik haftasının $31,4 \pm 4,2$ hafta ve fetüsün

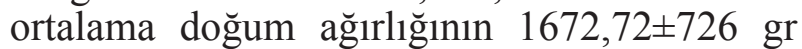
olduğu görüldü. HELLP sendomu tanıs1 alan hastaların 25 tanesinin kliniğimize müracaat ettiğinde intra uterin ölü fetüs olduğu tespit edildi. Yirmi hastanın postpartum dönemde kliniğimize kabul edilmesi, 34 bebeğin ise hastanemiz yenidoğan ünitesine girmeden diş merkezlerin yeni doğan ünitelerine sevk edilmesi nedeniyle toplam 76 yenidoğanın perinatal sonuçları değerlendirildi (Tablo 4).
Tablo 4: HELLP sendromu tanısı alan hastalarda gelişen perinatal komplikasyonlar.

\begin{tabular}{|l|l|}
\hline \multicolumn{1}{|c|}{ Perinatal Komplikasyonlar } & \multicolumn{1}{c|}{ n (\%) } \\
\hline Respiratuar distres sendromu (RDS) & $20(26,3)$ \\
\hline Prematüre retinopatisi (ROP) & $5(6,5)$ \\
\hline Nekrotizan enterokolit (NEK) & $6(7,8)$ \\
\hline Sepsis & $3(3,9)$ \\
\hline Bronkopulmoner displazi & $1(1,3)$ \\
\hline Mekanik ventilatör ihtiyacl & $11(14,4)$ \\
\hline Fototerapi intiyacl & $21(27,6)$ \\
\hline Perinatal mortalite & $9(11,8)$ \\
\hline
\end{tabular}

Maternal komplikasyon gelişmeyen ve en az bir tane maternal komplikasyon tespit edilen hastaların demografik özelliklerive laboratuar parametreleri karșılaștırıldı. Gruplar arasında demografik özellikler benzerdi ( $p>0.05)$. Gruplar arasinda AST, LDH, kreatinin, total bilirubin, trombosit ve hemoglobin değerleri açısından istatistiksel olarak önemli fark mevcuttu $(\mathrm{p}<0.05)$ (Tablo 5).

Tablo 5: En az bir maternal komplikasyon gelişen ve gelişmeyen olguların laboratuar ve klinik parametrelerinin karşılaştrıılması.

\begin{tabular}{|c|c|c|c|}
\hline & $\begin{array}{c}\text { Marternal } \\
\text { komplikas- } \\
\text { yon görülen } \\
\text { hastalar } \\
(\% 72,2)\end{array}$ & $\begin{array}{c}\text { Maternal } \\
\text { komplikasyon } \\
\text { görülmeyen } \\
\text { hastalar } \\
(\% 27,8)\end{array}$ & P değeri \\
\hline Yaş (Yıl) & $29,6 \pm 6,0$ & $30,1 \pm 7$ & 0,701 \\
\hline Gravite & $3,6 \pm 2,7$ & $3,1 \pm 2,6$ & 0,578 \\
\hline Parite & $2,2 \pm 2,4$ & $2,0 \pm 2,4$ & 0,487 \\
\hline Gebelik haftası & $31,28 \pm 4,6$ & $31,69 \pm 3,5$ & 0,578 \\
\hline $\begin{array}{l}\text { Sistolik kan ba- } \\
\text { sıncı (mmHg) }\end{array}$ & $158,6 \pm 30,7$ & $159,45 \pm 23,0$ & 0,858 \\
\hline $\begin{array}{l}\text { Diastolik } \\
\text { kan basıncı } \\
(\mathrm{mmHg})\end{array}$ & $96,9 \pm 16,5$ & $100,0 \pm 15,0$ & 0,163 \\
\hline AST (U/L) & $462,25 \pm 553,0$ & $295,50 \pm 249,0$ & $0,036^{*}$ \\
\hline $\mathrm{ALT}(\mathrm{U} / \mathrm{L})$ & $286,95 \pm 496$ & $246,30 \pm 288$ & 0,524 \\
\hline $\mathrm{LDH}(\mathrm{U} / \mathrm{L})$ & $1812,30 \pm 1814$ & $1115,18 \pm 680,0$ & $0,007^{*}$ \\
\hline $\begin{array}{l}\text { Kreatinin (mg/ } \\
\mathrm{dL})\end{array}$ & $1,8 \pm 2,0$ & $0,7 \pm 0,18$ & $0,000 *$ \\
\hline $\begin{array}{l}\text { Trombosit } \\
\text { sayısı(103/L) }\end{array}$ & $60000 \pm 43000$ & $83000 \pm 45000$ & $0,002^{*}$ \\
\hline $\begin{array}{l}\text { Total bulirubin } \\
\text { (mg/dL) }\end{array}$ & $3,21 \pm 3,4$ & $1,51 \pm 2,1$ & $0,002^{*}$ \\
\hline $\begin{array}{l}\text { Hemoglobin } \\
\text { (g/dL) }\end{array}$ & $14,36 \pm 1,2$ & $13,39 \pm 2,2$ & $0,004^{*}$ \\
\hline
\end{tabular}




\section{TARTIŞMA}

HELLP sendromu, maternal mortalite ve morbiditenin yüksek olduğu, ani ve hızla kötüleşebilen klinik bir tablodur. Hemoliz, karaciğer enzimlerinin artışı ve trombosit sayısının düşmesiyle karakterize bu sendromun tanımı için kesin kriterler konulamamıştır [5].

Çalışmamızın sonuçlarına göre, HELLP sendromu tanısı alan hastaların \%61'i multipar, \%39'u primipar gebeliğe sahipti. Sonuçlarımizla uyumlu olarak, Ahmed ve ark. [7] HELLP sendromu tanisı alan hastalarının \%62,5 oranında multipar, \%37,5 oranında primipar hastalardan oluştuğunu rapor etmişlerdir. Sadaf ve ark. [8] da HELLP sendromu tanisi alan hastaların çoğunluğunun $\% 72$ oran ile multipar hastalar olduğunu bildirmişlerdir. Bezircioğlu ve ark. [9] da benzer sonuçları bildirmiş olup, \%59 ile multipar hastalarda daha yüksek oranda HELLP sendromu vakası rapor etmişlerdir.

HELLP sendromu genç hasta popülasyonunda ve tipik olarak 27. gebelik haftası ile doğum arasındaki dönemde görülmekle birlikte, vakaların \%15-30'u erken postpartum dönemde ortaya çıkar [7-9]. Kınay ve ark. [10] HELLP sendromu tanısı almış hastalarının yaş ortalamasını $29,53 \pm 5,50$ y1l, ortalama gebelik haftasını 29,10 \pm 3,08 olarak bildirmişlerdir. Bezircioğlu ve ark. [9] ise HELLP sendromu tanısı almış hastalarının yaş ortalamasını $28,93 \pm$ 7,90 y1l, ortalama gebelik haftasın $33,68 \pm 4,41$ olarak bildirmişlerdir. Bu sonuçlara benzer olarak, çalışmamızda literatür ile uyumlu olarak ortalama maternal yaş $29,81 \pm 6,0$ yıl, ortalama gebelik haftası ise 31,4 4,2 olarak bulundu. 98 hastamızda gebeliğin 27-36. haftaları arasında (\%64) bu hafta aralığında teşhis konulmuşdu.

HELLP sendromu yönetimindeki temel hedef, maternal ve perinatal risk değerlendirmesiyle, doğum için gerekli en doğru zamanı ve yolu belirlemektir. HELLP sendromunda kötü maternal sonucu önceden predikte edebilecek risk faktörlerini tespit etmek için çalışmalar yapılmıştır $[5,8]$. Curiel-Balsera E ve ark. [11] HELLP sendromlu hastalarda maternal komplikasyon gelişmesi ile klinik ve laboratuar bulguları arasında bir ilişki olup olmadığını incelemişlerdir. Yaş, obesite, sigara içimi, gebelik say1s1, gebelik haftası, sistolik ve diastolik kan basınc1 değerleri, trombosit sayısı, AST ve ALT değerleri ile maternal komplikasyon gelişme durumu arasında herhangi bir ilişki olmadığını bildirmişlerdir. Ancak maternal komplikasyon gelişen hastalarda hemoglobin değerlerinin daha düşük olduğunu rapor etmişlerdir. Haddad ve ark. [12] ise HELLP sendromlu hastalarda trombositopeni mevcudiyetinin maternal komplikasyonları arttırdığını, ancak AST ve LDH seviyesindeki artışların maternal komplikasyonlar ile ilişkili olmadığını tespit etmişlerdir. Kumru [13] trombositin $<70.000$ 1/mm3, AST'nin > $400 \mathrm{IU} / \mathrm{L}$, ALT'nin > 400 IU/L, kreatinin $>2 \mathrm{mg} / \mathrm{dl}$ olmasının kötü maternal sonuç ile ilişkili olabileceğini belirtmişlerdir. Ayrıca maternal komplikasyon gelişmeyen hastalar ile en az bir adet komplikasyon gelişen hastaların laboratuar parametreleri arasında anlamlı farklılık olduğunu tespit etmişler. Komplikasyonlu grupta trombosit sayısını düşük, karaciğer fonksiyon testlerini yüksek bulmuşlardır. Martin [14] trombositopeniyle beraber AST, ALT, LDH ve kreatinin değerlerinin yüksekliğinin maternal morbiditeyi arttırdığını belirtmişlerdir. Magann [15] AST ve LDH seviyelerindeki artışlar ile kötü maternal sonuçlar arasında anlamlı ilişki olduğu tespit edilmiştir. Tanı konulduktan sonra, takipteki en iyi belirteçin trombosit sayısı olduğunu belirtilmiştir [16].

Remore Arauz JF [17] trombosit say1s1 ve maternal mortalite arasındaki ilişkiyi inceledikleri çalışmalarında, maternal mortalite gelişen 8 hastadan 7'sinin trombosit say1s1 50.000'nin altında tespit edilmiş. Çalışmamızda ortalama trombosit değeri $68000 / \mathrm{mm} 3$ olarak tespit edildi. Hastaların \%14'de trombosit sayıs1 $\geq$ $100.000 \mathrm{~mm} 3, \% .39$ 'da $50.000-100.000 \mathrm{~mm} 3$ arasında, \%45'inde ise $\leq 50.000 \mathrm{~mm} 3$ idi. Çalıșmamızda HELLP sendromu tanısı alan maternal komplikasyon gelişmeyen hastalar ile en az bir adet komplikasyon gelişen hastalar arasinda AST, LDH, kreatinin, trombosit sayıs1, total bulirubin değerleri açısından istatistiksel olarak anlamlı farklılık olduğunu gözlemledik. Trombosit seviyelerinin çok düşmesi prognozu olumsuz yönde etkileyebilmektedir.

HELLP sendromlu hastaların çoğunda hipertansiyon tespit edilmesine rağmen \%15 hastada hipertansiyon saptanmayabilir. Proteinürinin şiddeti, hastalığın ciddiyetini yansıtmayabilir [5]. Sibai [5] yaptığı çalışmada HELLP sendromlu olgularin \%9'unda spot idrarda proteinüri sadece bir pozitifdir ve $\% 6$ 'sinda proteinüri tespit edilmemiştir. Bizim çalışmamızda ise 4 hastada (\%2.6) proteinüri saptanmadi. $\mathrm{Bu}$ sonuç HELLP sendromu nonproteinürik, normotansif hastalarda gelişebileceğini göstermektedir.

HELLP sendromunun acil müdahale gerektirdiği için, sıklıkla tercih edilen doğum şekli sezaryendir. Literatürde HELLP sendromlu hastalarda sezaryen oranın $\% 75-\% 85$ olarak bildiren çalışmalar vardır $[18,19]$. 
Sibai [20] \%42, Yücel [21] \%90, Sofuoğlu [22] \%60, Rodriguez [23] \%97.5 olarak rapor etmişlerdir. Bizim sezaryen oranımız \%97,4 olup, bu yüksekliğin muhtemel nedeni gebelik haftasının küçük olması nedeniyle doğum indüksiyonu için servikal olgunluğun yetersiz olmasından kaynaklandığı düşündük.

HELLP sendromlu hastalarda mortaliteyi etkileyen önemli faktörlerden birisi mekanik ventilatöre bağlanma gerekliliği ve yoğun bakım ihtiyacıdır. Osmanağaoğlu ve ark. [18] mekanik ventilasyon ihtiyacının \%30, Murray ve ark. [19] ise 20 vakalık çalıșmalarında hastaların \% 70'inde yoğun bakım ihtiyacı gerektiğini bildirmişlerdir. Bir diğer çalışmada yoğun bakıma kabul edilen hasta oran1 \%64 olarak rapor edilmiştir [24]. Bizim çalışmamızda ise mekanik ventilasyon ihtiyacı olan hasta oranı \%13,5 idi. Sadaf ve ark. [8] HELLP sendromlu hastalarda maternal mortalite oranını $\% 0$, Sibai ve ark. [5] \%1,1 olarak bildiriken, çalıșmamızda bu oran \%13,5 olarak bulundu. Muhtemelen mekanik ventilatör ihtiyacının diğer merkezlerden düşük olması hastaların klinik tablosu ağırlașmadan doğum kararı alınmasına bağlanabilir.

Maternal mortalite bakımından değerlendirildiğinde, HELLP sendromu birçok obstetrik problemin önünde gelen hastalıktır. 20 yıl öncesinde bu riskin $\% 20$ civarında olduğu bildirilirken, günümüzde gelişmiş ülkelerde bu riskin $\% 0-6,5$ arasında olduğu rapor edilmektedir [5, 12]. Taner [25] 35 vakalık çalışmasında maternal mortalite oran $1 \% 2,85$, Sibai [20] 442 vakalık çalışmasında maternal mortalite oranınını $\% 1,1$, Erden [26] çalışmasında \%0,24 olarak belirmiştir. Bizim çalışmamızda mortalite oranı $12(\% 7,7)$ olup, mortalite ile sonuçlanan hastaların büyük çoğunun takipsiz gebelerden ve bizim kliniğimize entübe sevk edilen hastalardan oluşmaktaydı. Bölgemizin düşük sosyoekonomik seviyede olması sebebi ve hastaların çoğu klinik tablo kötüleşince hastaneye başvurması tedavinin başarı şansını azalmaktadır.

Perinatal mortalite açısından değerlendirildiğinde, çalışmamızda HELLP sendromu tanıs1 alan hastaların 25 tanesi $(\% 16,2)$ kliniğimize müracaat ettiğinde intrauterin ölü fetüs tanısı aldı. Yenidoğan kayıtlarına ulaşılan 76 yenidoğan bebeğin ise 9'u $(\% 11,8)$ doğumdan sonraki ilk yedi gün içinde kaybedildi. Sonuçlarımız literatürdeki çalışmaların sonuçlarına benzer olup, Bezircioğlu ve ark. [9], Kumru ve ark. [13] ve Sadaf ve ark. [8] HELLP sendromlu hastalarda intrauterin ölü fetüs oranını $\% 6,8$, $\% 27,3$ ve $\% 22,5$ doğumdan sonraki ilk yedi gün içinde yenidoğan ölüm oranını $\% 25, \% 18,8$ ve $\% 57,5$ olarak bildirmișlerdir.
Doğum anındaki gestasyonel yaş, perinatal mortalite ve morbidite için önemli faktördür. Kliniğimize intrauterin ex fetüs olarak gelen hasta sayısının yüksek olmasını takipsiz gebeliklerin fazla olmasına bağlı olabileceğini düşünmekteyiz.

Sonuç olarak, HELLP sendromunda hızlı tanı konulması ve etkin yönetim HELLP sendromunun prognozunu belirlemede en önemli noktalardır. Erken tanı için düzenli antenatal takip önemlidir. HELLP sendromu yönetimindeki temel hedef doğum için gerekli en doğru zamanı belirlemektir.

\section{KA Y N A KL A R}

1. Weinstein L. Syndrome of hemolysis, elevated liver enzymes and low platelet count: A severe consequence of hypertension in pregnancy. Am J Obstet Gynecol 1982;142(2):159-67.

2. O'Brien JM, Barton JR. Controversies with the diagnosis and management of HELLP syndrome. Clinical Obstetrics and Gynecology 2005;48(2):460-77.

3. Aloizos S, Seretis C, Liakos N, Aravosita P, Mystakelli C, Kanna E, et al.HELLP syndrome: understanding and management of a pregnancy-specific disease.J Obstet Gynaecol 2013;33(4):331-7.

4. Barton JR, Sibai BM. Diagnosis and management of hemolysis, elevated liver enzymes, and low platelets syndrome. Clin Perinatol 2004;31(4):807-33.

5. Sibai BM, Taslimi MM, el-Nazer A, Amon E, Mabie BC, Ryan GM. Maternal-perinatal outcome associated with the syndrome of hemolysis, elevated liver enzymes, and low platelets in severe preeclampsia-eclampsia. Am J Obstet Gynecol 1986;155(3):501-9.

6. Wada H. Disseminated intravascular coagulation. Clinica Chemica Acta 2004;344(1-2):13-21.

7. Ahmed FA, Amin A, Naeem NK. HELLP syndrome, a clinical variant of pre eclampsia. Annals 2007;13(2):158-61.

8. Sadaf N, Haq G, Shukar-ud-Din S.Maternal and foetaloutcome in HELLP syndrome at tertiary carehospital. J Pak Med Assoc 2013;63(12):1500-3.

9. Bezircioğlu İ,Baloğlu A,Çetinkaya B,Pirim B.Do clinical and laboratory paremeters effect maternal and fetal outcomes in pregnancies complicated with hemolysis, elevated liver enzymes, and low platelet count syndrome? J TurkishGerman Gynecol Assoc 2012;13:1-7.

10. Kınay T, Küçük C, Kayıkçıŏlu F, Karakaya J. Severe preeclampsia versus HELLP syndrome: maternal and perinatal outcomes at $<34$ and $\geq 34$ weeks'gestation.Balkan Med J 2015;32:359-63.

11. Curiel-Balsera E, Prieto-Palomino MA, Muñoz-Bono J, Ruiz de Elvira MJ, Galeas JL, Quesada García G. Analysis of maternal morbidity and mortality among patients admitted to Obstetric Intensive Care with severe preeclampsia, eclampsia or HELLP syndrome. Med Intensiva 2011;35(8):478-83. 
12. Haddad B, Barton JR, Livingston JC, Chahine R, Sibai BM. HELLP (hemolysis, elevated liver enzymes, and low platelet count) syndrome versus severe preeclampsia: onset at $<$ or $=28.0$ weeks' gestation. Am J Obstet Gynecol 2000;183(6):1475-9.

13. Kumru P, Kartal Ö, Köse G. The Evaluation of Cases with HELLP Syndrome. Perinatal Journey 2005;13:15-23

14. Martin JR, James N, Warren LM, Blake RN. Early risk assessment of severe preeclampsia: Admission battery of symptoms and laboratory tests to predict likelihood of subsequent significant maternal morbidity. Am J Obstet Gynecol 1999;180:1407-14.

15. Magann EF, Martin JN. Twelve steps to optimal management of HELLP syndrome. Clinical Obstetrics and Gynecology 1999; 42(3): 532-50.

16. Martin JN Jr, Blake PG, Perry KG Jr, McCaul JF, Hess $L W$, Martin RW. The natural history of HELLP syndrome: patterns of disease progression and regression. Am J Obstet Gynecol 1991;164(6): 1500-9.

17. Romero Arauz JF, Ramos Leon JC, Izquierdo Puente JC. Maternal morbidity and mortality in HELLP Syndrome. Ginecol Obstet Mex. 2001;69: 189-93.

18. Osmanagaoglu MA, Osmanagaoglu S, Ulusoy H, Bozkaya H. Maternal outcome in HELLP syndrome requiring intensive care management in a Turkish hospital. Sao Paulo Med J. 2006;124(2):85-8.
19. Murray D, O'Riordan M, Geary M, Phillips R, Clarke T, McKenna P. The HELLP syndrome, maternal and perinatal outcome. Ir Med J 2001;94(1):16-8.

20. Sibai BM, Ramadan MK, Usta I et al. Maternal morbidity and mortality in 442 pregnancies with hemolysis, elevated liver enzymes, and low platelets. Am J Obstet Gynecol 1993;169:1000.

21. Yücel MA, Pakdemir S, Eraslan S. HELLP sendromunda primer tedavi. Jinekoloji ve Obstetrik Dergisi 1997;11:92-5.

22. Sofuoğlu K, Kuyumcu U, İnmaz A. Preeklampsi ve eklampsi takip ve tedavi. 82 olgu analizi. Zeynep Kamil Tip Bülteni 1998;30:145-8.

23. Rodriguaz B, Perez PC, Perez JR. Maternal and perinatal surgical complications in low platelet count for HELLP syndome in severe preeclampsia in intensive care. Gynecol Obstet Mex 2003:71:379-86.

24. Fitzpatrick KE, Hinshaw K, Kurinczuk JJ, Knight M. Risk factors, management, and outcomes of hemolysis, elevated liver enzymes, and low platelets syndrome and elevated liver enzymes, low platelets syndrome. Obstet Gynecol 2014;123(3):618-27.

25. Taner CE, Erden AC, Kocabağll C. HELLP sendromlu 12 olgu ve tedavi yaklaşımları. Anatolian J Gynecol Obstet 1993;3:129.

26. Erden AC, Yayla M. Preeklampsi ve eklampside maternal fetal morbidite ve mortalite. Perinatoloji dergisi 1993;1:2430. 